\title{
EGR3 wt Allele
}

National Cancer Institute

\section{Source}

National Cancer Institute. EGR3 wt Allele. NCI Thesaurus. Code C118520.

Human EGR3 wild-type allele is located within 8p23-p21 and is approximately 6 kb in length. This allele, which encodes early growth response protein 3 , is involved in biological rhythms, muscle development, and the growth and migration of endothelial cells. 